\title{
Analyzing precipitationsheds to understand the vulnerability of rainfall dependent regions
}

\author{
P. W. Keys ${ }^{1, *}$, R. J. van der Ent ${ }^{2}$, L. J. Gordon ${ }^{1}$, H. Hoff ${ }^{3,4}$, R. Nikoli ${ }^{2}$, and H. H. G. Savenije ${ }^{2}$ \\ ${ }^{1}$ Stockholm Resilience Centre, Stockholm University, Stockholm, Sweden \\ ${ }^{2}$ Department of Water Management, Faculty of Civil Engineering and Geosciences, Delft University of Technology, \\ Delft, The Netherlands \\ ${ }^{3}$ Stockholm Environment Institute, Kräftriket 2b, 10691 Stockholm, Sweden \\ ${ }^{4}$ Potsdam Institute for Climate Impact Research, Telegrafenberg, Potsdam, Germany \\ *now at: Keys Consulting Inc., Seattle, WA, USA
}

Correspondence to: P. W. Keys (patrick@keysconsultinginc.com)

Received: 7 October 2011 - Published in Biogeosciences Discuss.: 26 October 2011

Revised: 17 January 2012 - Accepted: 23 January 2012 - Published: 10 February 2012

\begin{abstract}
It is well known that rivers connect upstream and downstream ecosystems within watersheds. Here we describe the concept of precipitationsheds to show how upwind terrestrial evaporation source areas contribute moisture for precipitation to downwind sink regions. We illustrate the importance of upwind land cover in precipitationsheds to sustain precipitation in critically water stressed downwind areas, specifically dryland agricultural areas. We first identify seven regions where rainfed agriculture is particularly vulnerable to reductions in precipitation, and then map their precipitationsheds. We then develop a framework for qualitatively assessing the vulnerability of precipitation for these seven agricultural regions. We illustrate that the sink regions have varying degrees of vulnerability to changes in upwind evaporation rates depending on the extent of the precipitationshed, source region land use intensity and expected land cover changes in the source region.
\end{abstract}

\section{Introduction}

Surface watersheds, delineated by topography, are considered the physical boundary for managing surface water resources, including the management of upstream activities that influence downstream water flows (e.g. Rockström et al., 2009). Spatial boundaries for the origin of precipitation have been suggested in previous work (e.g. Dirmeyer and Brubaker, 2007; Dirmeyer et al., 2009), and recently the importance of terrestrial evaporation has been identified as a significant source of precipitation for some areas globally (e.g. van der Ent et al., 2010). Additionally, recent analyses of land cover changes indicate that human-induced land cover changes can significantly alter the volume of evaporated moisture in the atmosphere (e.g. Boucher et al., 2004; Gordon et al., 2005; Rost et al., 2008). We integrate these breakthroughs into the concept of the precipitationshed, defined as the upwind atmosphere and surface that contributes evaporation to a specific location's precipitation (e.g. rainfall). We apply the precipitationshed as a tool for better understanding the vulnerability of rainfall dependent regions (e.g. dryland rainfed agriculture).

The paper is organized as follows. First, we explore the specific developments in the understanding of moisture recycling and the importance of rainfed agriculture, which led to the development of the precipitationshed concept. Second, we describe the data and methods used to identify critical precipitation sink regions and the precipitationsheds for those sink regions. Third, we examine the land cover found within each precipitationshed and how these contribute through evaporation to downwind precipitation and how that contribution might change with land cover changes. Finally, we describe future research needs to further develop and apply the precipitationsheds concept. 


\section{Background}

\subsection{Rainfed agriculture}

Throughout the world, humans depend on precipitation for a variety of ecosystem services (Millennium Ecosystem Assessment, 2005). One of the most crucial, yet vulnerable, ecosystem services is food production generated from rainfed agriculture in drylands. Rainfed agriculture in drylands constitutes the dominant livelihood for about 500 million people, or $8 \%$ of the world's population, many of whom live in persistent poverty (Rockström and Karlberg, 2009). Furthermore, drylands are characterized by extreme precipitation variability and low soil fertility (Reynolds et al., 2007), creating additional challenges for sustainable livelihoods. Securing and even improving water availability for current and future food production in these regions is imperative for food security and economic development (Rockström et al., 2009). However, improvements in food production through irrigation are limited in these regions since surface water (i.e. water in aquifers, lakes and streams) is scarce and can only be made productive in societies with access to, or means to develop, irrigation infrastructure (Molden, 2007). Future increases in food production must thus primarily come from rainfed agriculture that relies on soil moisture (replenished by precipitation) (e.g. Savenije, 2000; Molden, 2007; Rockström et al., 2009; Foley et al., 2011).

\subsection{Moisture recycling}

In general, precipitation originates as evaporation from the oceans or as recycled moisture from terrestrial surfaces (van der Ent et al., 2010). External forcings and climate feedbacks (e.g. solar radiation, aerosols and greenhouse gasses) influence sea surface temperature, and thus largely determine ocean evaporation (Soden and Held, 2006). Terrestrial evaporation on the other hand, though in part influenced by climate (Bichet et al., 2011), is strongly influenced by terrestrial vegetation (Gerten et al., 2004; Gordon et al., 2005; Rost et al., 2008), which itself also has bi-directional feedbacks with the climate system (Feddes et al., 2001; Millán et al., 2005; Li et al., 2007; Pielke Sr et al., 2007; Pitman et al., 2009; Kochendorfer and Ramírez, 2010; Dallmeyer and Claussen, 2011).

The study of moisture recycling, the process by which surface evaporation returns to the land surface as precipitation (e.g. Budyko, 1974; Lettau et al., 1979; Koster et al., 1986; Brubaker et al., 1993; Eltahir and Bras, 1994; Savenije, 1995), can be useful in quantifying to what extent precipitation is dependent on local (versus external) or terrestrial (versus oceanic) evaporation and thus helps assess the vulnerability of a region to local or external land cover changes (Lettau et al., 1979; Savenije, 1995; Kunstmann and Jung, 2007; Hossain et al., 2009; Jódar et al., 2010). In fact, recent studies show that large regions of Earth's terrestrial sur- face receive the majority of atmospheric moisture for precipitation from upwind, terrestrial evaporation (e.g. Numaguti, 1999; Bosilovich and Chern, 2006; Dirmeyer and Brubaker, 2007; Dominguez and Kumar, 2008; Dirmeyer et al., 2009; van der Ent et al., 2010). This suggests that terrestrial vegetation, and its associated evaporation, is a critical factor for downwind precipitation. Indeed, humans have already altered regional and global evaporation through land use and land cover change (Gordon et al., 2005; Rost et al., 2008) leading to regional and global impacts to the climate and the hydrological cycle (Boucher et al., 2004; Feddema et al., 2005; Pielke Sr et al., 2007). Although moisture recycling can be local, it often connects geographically separate regions with bridges of atmospheric moisture transport, linking upwind evaporation sources with downwind precipitation sinks (e.g. Bosilovich and Chern, 2006; Dirmeyer er al., 2009; van der Ent et al., 2010).

\subsection{The precipitationshed}

The concept of the precipitationshed can be thought of as an "atmospheric watershed". The precipitationshed is for precipitation dependent ecosystems what the surface watershed is for surface water dependent ecosystems (Fig. 1), and it is defined as the upwind atmosphere and upwind terrestrial land surface that contributes evaporation to a specific location's precipitation (e.g. rainfall). In this paper we use the conceptual framework of precipitationsheds to illustrate how land cover change in one region could affect evaporation, and thus precipitation, in a geographically separate region. An important distinction is that precipitationshed boundaries are not deterministic (as with a watershed) but probabilistic. In other words, they do not have fixed and deterministic boundaries, but depend rather on a threshold of contribution, on the period of integration, and the moment in time. Understanding the connection between upwind land cover and downwind precipitation may help to identify both risks and opportunities associated with land cover changes. This is particularly relevant for societies based on rainfed agriculture, because they already operate at the margins of productivity, so even a small decline in precipitation could have disproportionately large consequences for agricultural yields (Rockström et al., 2009).

\section{Data and methods}

Specific sink regions were required to empirically explore the precipitationsheds concept. Our aim is to identify regions that (1) are located in drylands, (2) contain a high percentage of rainfed cereal-grain agricultural land (growing maize, millet, and/or sorghum), and (3) receive greater than $50 \%$ of the growing season precipitation from upwind, terrestrial evaporation. We use data derived from global datasets (aridity, rainfed crop production, atmospheric data, Anthromes, 


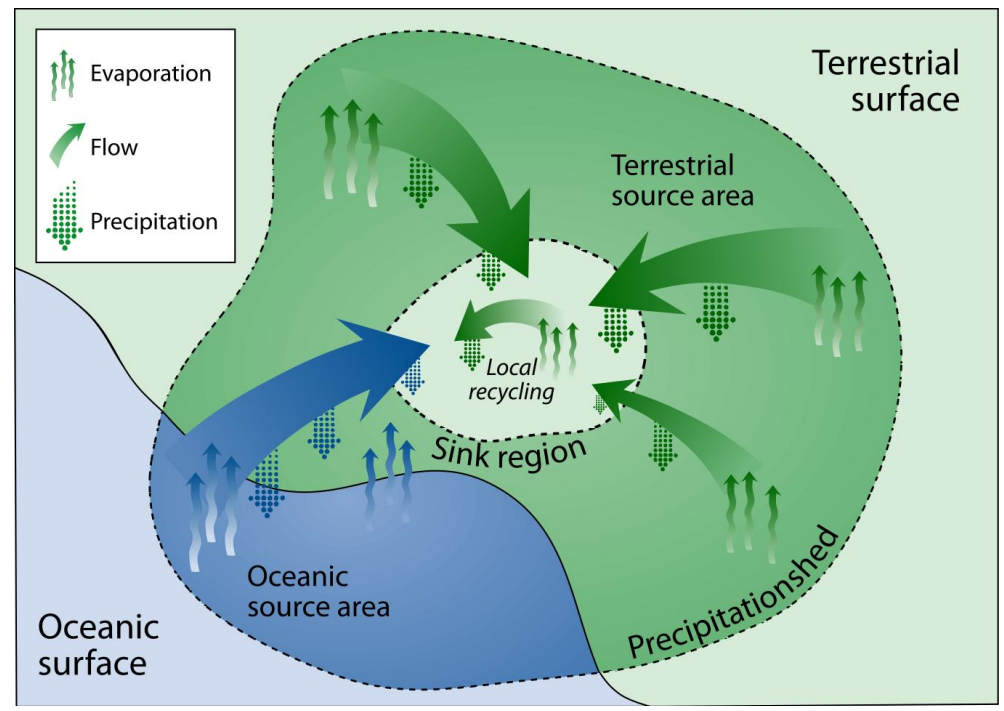

Fig. 1. Conceptual image of a precipitationshed, with precipitation in the sink region originating from both terrestrial and oceanic sources of evaporation.

population), and the results and conclusions are thus limited by the various resolutions of the data (ranging from $1.5 \mathrm{de}$ grees for the ERA Interim data, to 5 arc min for the rainfed cereal data). The reliability of these datasets is considered high, based on their current widespread use in the relevant fields.

\subsection{Dryland classifications}

We are interested in drylands where water is a limiting factor for agricultural production. Here we use a broad definition of these regions, building on Rockström and Karlberg's 2009 use of the FAO-developed Aridity Index $(A I)$ :

$A I=\frac{P}{E_{\mathrm{p}}}$

where $A I$ is the aridity index, $P$ is precipitation, and $E_{\mathrm{p}}$ is potential evaporation (Rockström and Karlberg, 2009). The AI was produced as a global dataset at the 30 arc min resolution, derived from measurements of reference evaporation using the Penman-Monteith equation (Allen et al., 1998), and climate variables from the CRU CL 2.0 dataset (New et al., 2002). Rockström and Karlberg (2009) reclassified the global dataset into four categories; arid $(A I \leq 0.20)$; semi-arid ( $A I 0.20$ to $\leq 0.50$ ); dry-subhumid ( $A I 0.50$ to $\leq 0.65$ ), and humid $(A I \geq 0.65)$. Using these classified areas, we categorize arid and semi-arid as water-constrained, and it is found that $50 \%$ of the earths terrestrial land surface falls in this category.

\subsection{Rainfed cereal data}

Global food production has been quantified and gridded with increasing accuracy and resolution over the last decade (e.g.
Ramankutty and Foley, 1998; Ramankutty et al., 2008; Monfreda et al., 2008; Thenkabail et al., 2009; Portmann et al., 2010). Major efforts to utilize fine scale resolution satellite data have yielded detailed global land cover maps, including both irrigated and rainfed croplands. Ramankutty et al. (2008) and Monfreda et al. (2008) have produced a fine resolution, spatially explicit, agriculture dataset that provides specific cropping calendars for individual grid cells. Portmann et al. (2010) developed the Monthly Irrigated and Rainfed Crop Areas around the year 2000 (MIRCA2000) dataset which was built largely upon the dataset produced by Ramankutty et al. (2008) and Monfreda et al. (2008). There are several datasets available within the MIRCA2000 package, but this analysis requires several specific factors: area harvested for rainfed agriculture, growing season months, and crop types. Out of the available MIRCA2000 datasets, the cropping period list (CPL) dataset is most suitable for this research.

The CPL dataset was produced at a fine resolution ( 5 arc $\min$ ) and differentiated between rainfed and irrigated cultivation. The dataset includes 26 crop types, with up to six subcrops of a given crop type; subcrops being defined as the same crop planted during different growing seasons throughout the planting year. Finally, the dataset includes the area harvested and the specific monthly bounds for the growing season, for each crop.

Dryland cereals were chosen as the target crops for this analysis because they are the staples for many rainfed, smallholder farms. Maize, millet, and sorghum were selected because they share a similar growing season, whereas wheat was found to have a very different growing season. This growing season information was critical as this research aims to understand the specific growing season moisture recycling 
characteristics, not annual averages. Additional information on the datasets available in the MIRCA2000 dataset may be found in the online MIRCA2000 data portal; the link to the data portal is given in the references (Portmann et al., 2010).

\subsection{Sources of the growing season precipitation}

Following van der Ent et al. (2010), the continental precipitation recycling ratio $\rho_{c}$ (also referred to as the moisture recycling ratio, or recycling ratio) indicates which fraction of the precipitation originates from terrestrial evaporation sources:

$\rho_{c}=\frac{P_{c}}{P_{o}+P_{c}}=\frac{P_{c}}{P}$

where $P_{c}$ is precipitation of continental origin (i.e. most recently evaporated from a terrestrial source), and $P_{o}$ is precipitation of oceanic origin (i.e. most recently evaporated from an oceanic source). In this paper we use the water accounting model (WAM) of van der Ent et al. (2010) to compute $\rho_{c}$ for the growing season.

The meteorological input data for the WAM are taken from the ERA-Interim Reanalysis (Berrisford et al., 2009; Dee et al., 2011). We use precipitation and evaporation (3 $\mathrm{h}$ intervals), as well as: specific humidity, zonal and meridional wind speed at the lowest 24 pressure levels $(175-1000 \mathrm{hPa}$, hectopascals), and surface pressure (6 hour intervals) in order to calculate the vertically integrated, horizontal moisture fluxes and precipitable water. All meteorological data are available at a $1.5^{\circ}$ latitude $\times 1.5^{\circ}$ longitude grid. The data used in this analysis cover the period from 1999 to 2008 .

Limitations associated with vertically integrating moisture fluxes may include potential distortions in areas where there is large heterogeneity in the atmospheric column. For example, in West Africa, there can be near surface dynamics related to the Intertropical Convergence Zone (ITCZ), while the high altitude dynamics, such as the African or Tropical Easterly Jet, move in a different direction. However, as demonstrated by van der Ent et al. (2010), the large-scale features of regional and global moisture fluxes are preserved. We refer to van der Ent et al. (2010) and van der Ent and Savenije (2011) for further details on assumptions and limitations.

\subsection{Precipitationshed backtracking analysis}

In order to calculate the precipitationshed for a sink region (Fig. 1), we adapt the Water Accounting Model (WAM) of van der Ent et al. (2010), which allows for the backtracking of precipitation from a specific sink region in order to identify the sink's evaporative sources. For the adapted WAMbased backtracking method, it holds that:

$$
P_{\Omega}\left(t, x_{\Omega}, y_{\Omega}, A_{\Omega}, \varsigma \Omega\right)=\int_{i=0}^{p} \int_{j=0}^{m} E_{\Omega}\left(t, x_{i}, y_{i}\right)
$$

where $P_{\Omega}$ is the precipitation in the sink region $\Omega$ (defined by longitude $x_{\Omega}$, latitude $y_{\Omega}$, surface area $A_{\Omega}$ and a shape $\varsigma_{\Omega}$ ). Specifically, we calculated for each grid cell the amount of evaporation $E_{\Omega}$ going to the sink region $\Omega$, meaning that it travels through the atmosphere to end as precipitation $P_{\Omega}$ in the sink region $\Omega$. Integrating $E_{\Omega}$ over all grid cells, whereby $i$ and $j$ are the indices of the cells and $p$ and $m$ are the numbers of grid cells respectively along a parallel and a meridian it holds for the growing season $t$ that the precipitation in the sink region is equal to all evaporation that comes to the sink region.

\section{Results}

\subsection{Sink region identification}

Overlaying the maps of (1) dryland (water constrained) regions, (2) rainfed agricultural regions and (3) continental recycling dependent regions yields seven terrestrial recyclingdependent, water constrained, rainfed agricultural sink regions (hereafter, "sink regions") (Fig. 2). The reason there is not more overlap between water constrained areas and rainfed agricultural areas (brown and light blue, respectively in Fig. 2), is partly due to the fact that the water constrained classification includes arid and hyper-arid desert areas, where the only cultivation that occurs is fully irrigated. The areas that are both water constrained and contain rainfed agriculture (indicated in green) are further filtered based on the fraction of growing season precipitation that originates from terrestrial sources. This is depicted in Fig. 2 with the moisture recycling ratio scale ranging from $50 \%$ (yellow) to as high as $79 \%$ (royal blue) of growing season precipitation originating as terrestrial evaporation.

The seven sink regions are named based on the countries or regions in which they are located: Argentina, Southern Africa, the Western and Eastern Sahel, Pakistan-India, Eastern China, and Northern China. The sink regions range in size from 4.5 million to 137 million square kilometers (Table 1). Notably, growing season rainfall is less than 600 millimeters $(\mathrm{mm})$ per growing season in all sink regions, with most regions below $500 \mathrm{~mm}$. Also, these seven sink regions contain $53 \%$ of the globally cultivated hectares (ha) of rainfed maize (29\%), millet (70.5\%), and sorghum (38\%) occurring in water-constrained regions. This fraction of waterconstrained, rainfed cultivation is indeed significant and the areas are consistent with priority areas of global development (e.g. Rockström and Karlberg, 2009; Rockström et al., 2009; Boelee, 2011; Foley et al., 2011).

We chose to focus on sink regions that are strongly rainfall dependent. However, water supplies can enter these regions from other sources (e.g. surface runoff, groundwater) and there could be local hydrological interactions that are unaccounted for in our analysis. Any analysis of local scale hydrological interactions is both outside the scope of this work, 
Table 1. Characteristics of the recycling dependent water constrained rainfed agricultural regions (sink regions). The three staple crops used in this analysis (maize, millet, and sorghum) were grown in all seven of the sink regions. Evaporation and precipitation data were taken from the ERA-Interim archive.

\begin{tabular}{|c|c|c|c|c|c|c|}
\hline Region & $\begin{array}{l}\text { Area size } \\
\left(10^{6} \mathrm{~km}^{2}\right)\end{array}$ & Growing season & $\begin{array}{l}\text { Nations within } \\
\text { sink region }\end{array}$ & $\begin{array}{l}\text { Sum of the rainfall } \\
\text { during the growing } \\
\text { growing season }(\mathrm{mm})\end{array}$ & $\begin{array}{c}\text { Rainfall during the } \\
\text { season as a fraction of } \\
\text { the yearly precipitation }\end{array}$ & $\begin{array}{l}\text { Rainfall originating from } \\
\text { terrestrial sources during } \\
\text { the growing season }\end{array}$ \\
\hline Argentina & 4.5 & Nov-Mar & Argentina & 583 & $59 \%$ & $57 \%$ \\
\hline East China & 35 & May-Sep & China & 419 & $79 \%$ & $64 \%$ \\
\hline Eastern Sahel & 54 & Jun-Oct & Chad, Eritrea, Sudan & 452 & $93 \%$ & $59 \%$ \\
\hline North China & 20 & May-Sep & China & 334 & $81 \%$ & $72 \%$ \\
\hline Pakistan-India & 30 & Jul-Nov & India, Pakistan & 339 & $78 \%$ & $55 \%$ \\
\hline Southern Africa & 20 & Dec-Apr & Botswana, South Africa & 343 & $64 \%$ & $54 \%$ \\
\hline Western Sahel & 137 & Jun-Oct & $\begin{array}{c}\text { Benin, Burkina Faso, } \\
\text { Cameroon, Chad, Mali, } \\
\text { Mauritania, Niger, Nigeria }\end{array}$ & 301 & $93 \%$ & $64 \%$ \\
\hline
\end{tabular}

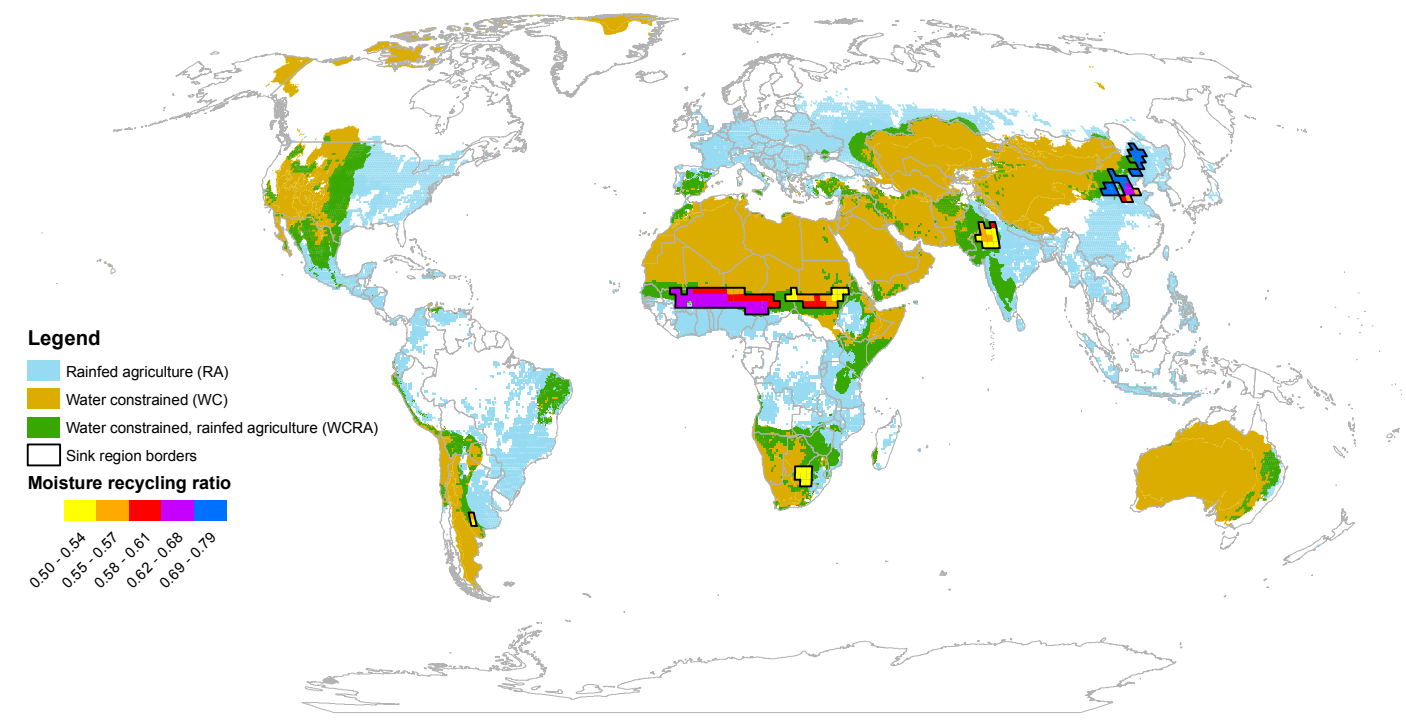

Fig. 2. Seven sink regions with rainfed agriculture, that are vulnerable to land cover change altering precipitation. The regions outlined in black are (a) located in water-constrained drylands (Portmann et al., 2010), (b) dominated by rainfed agriculture (Rockström and Karlberg, 2009), and (c) are dependent on terrestrial evaporation for more than $50 \%$ of their growing season precipitation (van der Ent et al., 2010). Note that even though the sink regions are not green (which would indicate they are a WCRA region), they are in fact all water-constrained and dominated by rainfed agriculture.

as well as beyond the resolution of the data and models employed in the analysis.

\subsection{Precipitationshed backtracking}

For each of the seven sink regions we obtain evaporation data that falls as growing season precipitation (gridded at the $1.5^{\circ}$ latitude $\times 1.5^{\circ}$ longitude resolution). This evaporation data can be expressed as absolute evaporation (Fig. 3a, first scale), as a fraction of the grid cell's total evaporation (Fig. 3b, first scale), or as a fraction of several grid cell's contribution to the total precipitation in the sink region (Fig. 3, second scale). However, this is not yet a spatially explicit precipitationshed. If every grid cell contributing even the smallest fraction of evaporation to sink region precipitation is included, the precipitationshed encompasses the entire globe (Eq. 3); this could be considered the $100 \%$ precipitationshed. However, most grid cells contribute very small amounts of evaporation, so in order to identify an analytically useful, spatially explicit boundary for the precipitationshed, a user-defined threshold must be set. After a preliminary sensitivity analysis, the $70 \%$ threshold was used to ensure that the origin of a considerable amount of the growing season precipitation was included, while still retaining a boundary that was analytically useful for the land-use and vulnerability analysis (see Fig. 4). Note that this user-defined threshold influences the shape and size of the precipitationshed (described in Fig. S1; also see Fig. 3 and S2-S7). 

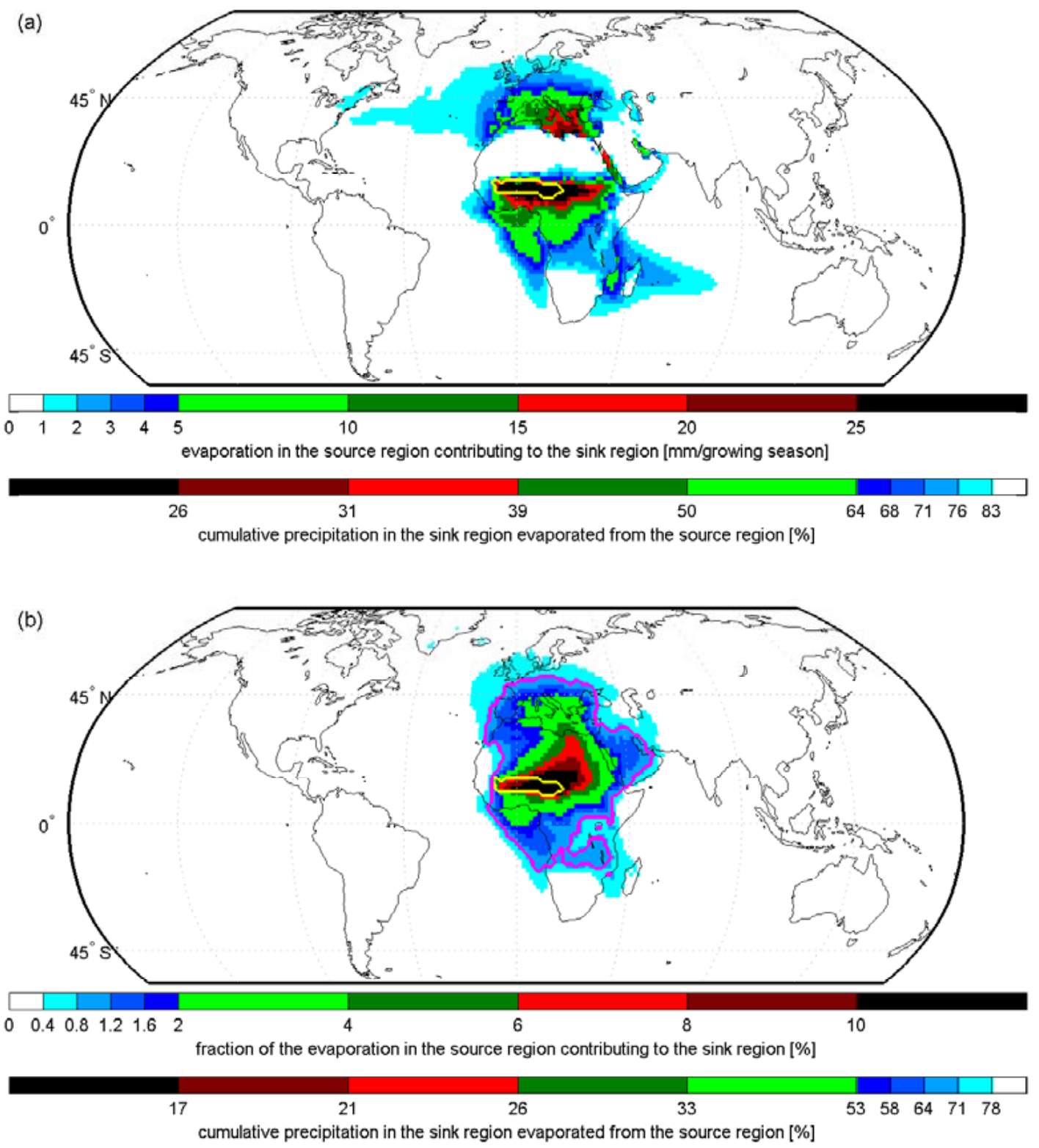

Fig. 3. Precipitationsheds of the West Sahel sink region: (a) The absolute precipitationshed of the West Sahel sink region (yellow border), expressed in terms of absolute evaporation mm/growing season contributed to sink region precipitation; (b) The relative precipitationshed of the West Sahel sink region (yellow border), expressed in terms of a fraction of the evaporation contributed to sink region precipitation. The second color scale in (a) and (b) indicates which percentage of the precipitation in the West Sahel region is generated within the area indicated by the corresponding colors. The pink border in (b) (= the gray border in Fig. 4) is the relative precipitationshed for the West Sahel region (at $70 \%$ contribution). The West Sahel sink region receives an average of $301 \mathrm{~mm}$ of precipitation per growing season. See Supplemental Figs. S2-S7 for the absolute and relative precipitationsheds of the other six sink regions.

The precipitationshed is more dynamic than the relatively static boundary of a surface watershed, given that the boundary is dependent on the defined threshold, and climatological phenomena that fluctuate both intra- and inter-annually. Furthermore, the precipitationshed boundaries depicted in Fig. 4 reflect the mean boundary for the years 1998-2008, which is the range for which reanalysis data were available. Understanding whether and how these boundaries might change with other climate variations from before or after this period is outside the scope of this study, but could be explored in future research. Additionally, the authors acknowledge that the El Nino Southern Oscillation (ENSO) or similar events could indeed alter the precipitationshed boundaries.

The interannual variability of the precipitationsheds analyzed in this paper is generally in the order of $8-35 \%$ of the average precipitationshed size. The maximum we found 
for Pakistan (35\%) and the minimum for North China, East China and West Sahel (8\%). For more details see Fig. S8 and Table S1.

\subsection{Precipitationshed of the West Sahel region}

With the West Sahel region as an example, Fig. 3 presents two different methods for visualizing and bounding the precipitationshed. Figure 3 a depicts the absolute precipitationshed, emphasizing the grid cells that contribute the largest absolute amount of evaporation to sink region precipitation. Fig. $3 \mathrm{~b}$ depicts the relative precipitationshed, emphasizing those grid cells from which the largest relative amounts of their evaporation contribute to sink region precipitation. While the absolute precipitationshed is useful for identifying the regions that currently contribute the most evaporation to sink region precipitation, the relative precipitationshed is useful for understanding where land cover changes would be particularly important, in terms of altered evaporation.

It should be noted that teleconnected phenomena are not included in these precipitationsheds, and only direct contributions of evaporation are represented. The influence of teleconnected phenomena (e.g. the El Niño Southern Oscillation, ENSO) is beyond the scope of this research, but is worth exploring in the future.

In both the absolute and relative precipitationshed of the Western Sahel (Fig. 3a and b) we can see a pattern where grid cells that are generally closer to the sink region contribute more both in absolute and relative terms. This is consistent with the precipitationsheds of the other sink regions (see Supplement Figs. S2-S7). Terrestrial surfaces represent $77 \%$ of the Western Sahel precipitationshed, while oceanic surfaces comprise the remaining $23 \%$ (Table 4).

A large amount of evaporation originates within the Western Sahel sink region (Fig. 3), which is an indicator of high local moisture recycling, which has been noted in other studies (Koster et al., 1986; Savenije, 1995; Nieto et al., 2006; Dekker et al., 2007; van der Ent and Savenije, 2011). There is no absolute contribution from the nearby Sahara (Fig. 3a), however, the large relative contribution suggests that enhanced absolute evaporation in the Sahara could have a large effect on the precipitation in the Sahel. The strong contributions evident in the Mediterranean region are potentially an artifact of the model being unable to resolve differences between humid and dry source regions. This issue has been identified in previous work, using similar methods, notably the work of Dirmeyer and Brubaker (2007).

The detailed precipitationsheds for the other six regions are shown in the Supplementary Figs. S2-S7. The 70\% precipitationshed boundaries are given for all regions in Fig. 4. For these precipitationsheds we analyze the land cover and identify the vulnerability of the sink regions to land cover changes.

\subsection{Precipitationsheds of all the sink regions}

Figure 4 illustrates the $70 \%$ precipitationshed boundary for all seven sink regions based on the relative precipitationsheds (Fig. 3b and Figs. S2b-S7b). It is apparent that the Argentina and the South-Africa regions obtain most of their precipitation from nearby, whereas the precipitationsheds of the other regions are much larger (see also Table 4). Also, the spatial extent and the shape of the precipitationsheds generally reflect prevailing storm tracks and wind directions.

Trans-desert moisture advection, such as that visible in Fig. 3 appears to provide much of the moisture for many of the sink regions, however might be overestimated by a posteriori moisture tracking models such as the WAM model.

Validation of the identified precipitationsheds is beyond the scope of this paper, however future work could apply multiple methods towards this end.

The absolute precipitationsheds are interrupted by vast areas of no contribution (e.g. if there is a desert), and then have significant contribution much further away (e.g. precipitationsheds of Western Sahel, Eastern Sahel, Pakistan-India, and Eastern China). The relative precipitationsheds are spatially contiguous (lacking the fragmentation of the absolute precipitationsheds), including areas of potential (but not current) evaporation contribution.

\section{Using the precipitationshed as a tool to understand vulnerability}

The strength of the precipitationshed approach is the explicit inclusion of the distant land surface that contributes evaporation to precipitation. This allows for the examination of the impacts of land cover change on evaporation rates and subsequent precipitation in downwind sink regions.

\subsection{Land cover and vulnerability}

We developed a qualitative framework to assess the sensitivity and susceptibility of sink region precipitation to land cover changes in the precipitationshed. The framework consists of two primary features:

1. Distribution of land cover and intensity of land use within each precipitationshed.

2. Plausible land cover changes in the precipitationshed that can substantially decrease, or increase evaporation.

This analysis uses the relative precipitationshed for each sink region (the $70 \%$ precipitationsheds in Fig. 4), because the relative boundary captures the potential contribution of each grid cell.

We use the Anthromes 2.0 dataset from Ellis et al. (2010) to characterize land cover in the precipitationsheds. Anthromes comes from the combination of the words anthropogenic and biomes, emphasizing the fact that nearly all 
Table 2. This table depicts the re-classification of the Anthromes 2.0 categories based on general land cover characteristics (Ellis et al., 2010).

\begin{tabular}{|c|c|c|c|}
\hline \multicolumn{2}{|c|}{ Original Anthrome Categories } & \multicolumn{2}{|c|}{ Re-classified Anthrome Categories } \\
\hline Dense & & Dense & \\
\hline \multirow[t]{2}{*}{ Settlements } & Urban & Settlements & Urban \\
\hline & Mixed & & Mixed \\
\hline \multirow[t]{4}{*}{ Villages } & Rice & Rice \& Irrigated & Rice \\
\hline & Irrigated & Cropland & Irrigated \\
\hline & Rainfed & & Residential irrigated croplands \\
\hline & Pastoral & Rainfed Cropland & Rainfed \\
\hline \multirow[t]{4}{*}{ Croplands } & Residential irrigated croplands & & Residential rainfed croplands \\
\hline & Residential rainfed croplands & & Populated rainfed cropland \\
\hline & Populated rainfed croplands & & Remote croplands \\
\hline & Remote croplands & Rangelands & Pastoral \\
\hline \multirow[t]{3}{*}{ Rangelands } & Residential rangelands & & Residential rangelands \\
\hline & Populated rangelands & & Populated rangelands \\
\hline & Remote rangelands & & Remote rangelands \\
\hline \multirow[t]{5}{*}{ Semi-natural lands } & & Woodland & Residential woodlands \\
\hline & Residential woodlands & & Populated woodlands \\
\hline & Populated woodlands & & Remote woodlands \\
\hline & Remote woodlands & & Wild woodlands \\
\hline & Inhabited treeless and barren lands & Barrenland & Inhabited treeless and barren lands \\
\hline \multirow[t]{2}{*}{ Wildlands } & Wild wildlands & & Wild treeless and barren lands \\
\hline & Wild treeless and barren lands & Oceans & Oceans \\
\hline No Data & No Data & No Data & No Data \\
\hline
\end{tabular}

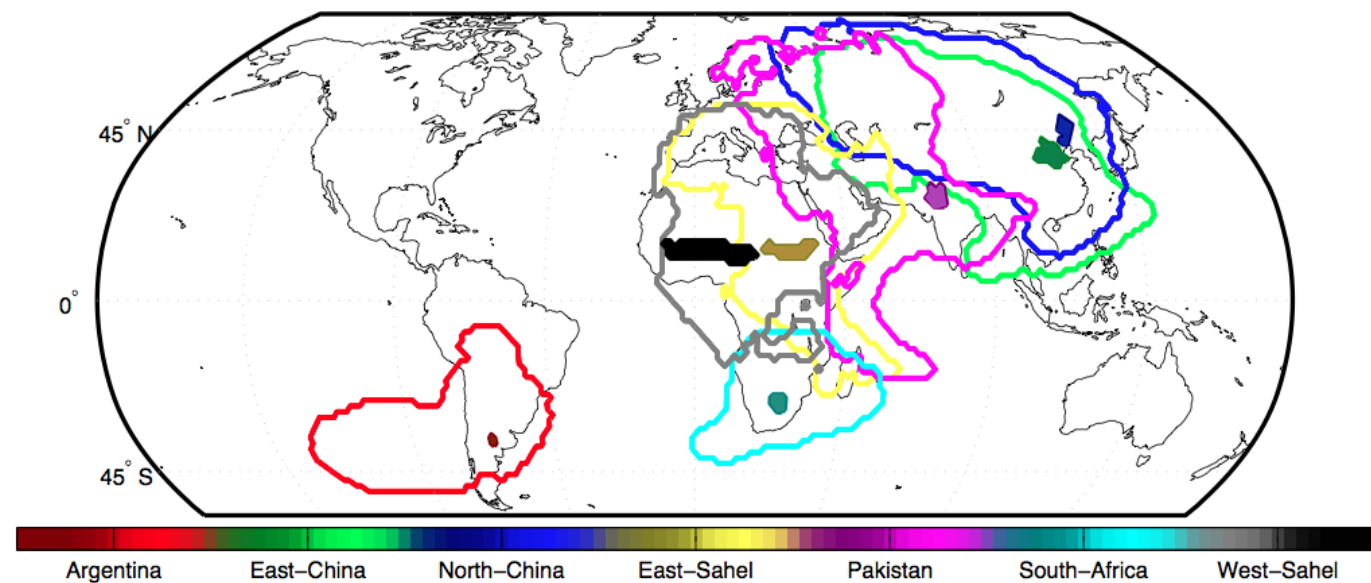

Fig. 4. The relative precipitationsheds (at $70 \%$ precipitation contribution) for all seven sink regions in this study. The darker colors indicate the sink regions (see Fig. 2) and the lighter colors indicate the precipitationshed borders. The gray border of the West-Sahel region corresponds with the pink border in Fig. 3b. The other colors corresponds to the pink border in Supplement Figs. S2b-S7b.

global terrestrial surfaces are now altered by human societies (Ellis and Ramankutty, 2008; Ellis et al., 2010). As compared to a conventional biomes dataset that only portrays terrestrial vegetation regardless of human activity, the Anthromes dataset was chosen for this analysis because the Anthromes dataset captures where and how land cover has changed through time, primarily due to human-induced changes.
We aggregated the 19 terrestrial Anthromes categories into 6 categories with similar evaporation characteristics (e.g. inhabited treeless \& barren lands are grouped with wild treeless $\&$ barren lands). In this way, the data were more easily interpreted in terms of potential evaporative effects from major land cover changes. The re-classification of land covers is described in Table 2. 
Table 3. Land use within the seven precipitationsheds, using the reclassified Anthromes.

\begin{tabular}{lllllllll}
\hline Precipitationshed & No Data & Ocean & Barrenland & Woodland & Rangeland & $\begin{array}{c}\text { Rainfed } \\
\text { cropland }\end{array}$ & $\begin{array}{c}\text { Rice and irrigated } \\
\text { cropland }\end{array}$ & $\begin{array}{c}\text { Dense } \\
\text { settlements }\end{array}$ \\
\hline Argentina & $1.8 \%$ & $23.0 \%$ & $25.8 \%$ & $10.7 \%$ & $20.8 \%$ & $15.6 \%$ & $1.5 \%$ & $0.8 \%$ \\
East China & $1.9 \%$ & $17.8 \%$ & $8.4 \%$ & $25.8 \%$ & $26.3 \%$ & $13.3 \%$ & $5.8 \%$ & $0.7 \%$ \\
Eastern Sahel & $2.7 \%$ & $24.1 \%$ & $21.5 \%$ & $10.0 \%$ & $22.5 \%$ & $16.1 \%$ & $2.2 \%$ & $0.9 \%$ \\
North China & $2.3 \%$ & $14.0 \%$ & $10.3 \%$ & $33.8 \%$ & $22.9 \%$ & $12.5 \%$ & $3.6 \%$ & $0.6 \%$ \\
Pakistan-India & $2.9 \%$ & $24.3 \%$ & $11.6 \%$ & $18.5 \%$ & $18.2 \%$ & $18.5 \%$ & $5.3 \%$ & $0.7 \%$ \\
Southern Africa & $1.1 \%$ & $55.7 \%$ & $0.7 \%$ & $6.5 \%$ & $31.0 \%$ & $4.7 \%$ & $0.2 \%$ & $0.1 \%$ \\
Western Sahel & $1.8 \%$ & $23.0 \%$ & $25.8 \%$ & $10.7 \%$ & $20.8 \%$ & $15.6 \%$ & $1.5 \%$ & $0.8 \%$ \\
Totals & $2.1 \%$ & $26.0 \%$ & $14.9 \%$ & $16.6 \%$ & $23.2 \%$ & $13.8 \%$ & $2.9 \%$ & $0.7 \%$ \\
\hline
\end{tabular}

Additionally, gridded population data were included in the analysis to characterize the precipitationsheds in terms of the raw number of people. The NASA-sponsored Socioeconomic Data and Applications Center (SEDAC) provided the Gridded Population of the World (GPW) version 3 dataset, for the year 2000 (CIESIN, 2005). The data were comprised of 400000 sub-national units (ranging from sub-national to national), and were gridded at the 0.5 degree resolution. The $70 \%$ precipitationsheds were intersected with the gridded population dataset to estimate the number of people that occupy each precipitationshed (Table 4).

Note that the vulnerability of a sink region is described in terms of sensitivity and susceptibility to land cover changes only. This analysis does not say anything about the vulnerability in terms of adaptive capacity.

\subsection{Results of the land cover analysis}

Aside from oceanic surfaces, the dominant land covers across the precipitationsheds are rangelands, closely followed by rainfed croplands, and woodlands (Table 3). This is important because rangelands are particularly susceptible to rapid and chaotic change (Lambin et al., 2001), from overstocking and pasture fragmentation leading to soil degradation, loss of species diversity, or loss of forage crops. This chaotic change often leads to a degraded or barren state, with correspondingly lower evaporation (Milton et al., 1994).

Based on current land cover, we assigned each precipitationshed a land use intensity ranging from very low to very high. For example, we defined rainfed croplands as more intense than rangelands, which were more intense than woodlands. This intensity rating was based on the continuum derived from population and land use in Ellis and Ramankutty (2008). All of the precipitationsheds are experiencing at least moderate land-use intensity, with most experiencing either high or very high. High land-use intensities were dominated by rangelands and rainfed croplands, while very high intensities also had significant rice and irrigated areas (Tables 3 and 4). Many of the sink regions experience a high percentage of internal moisture recycling, which refers to evaporation within the sink region falling as precipitation within the sink region. Therefore, internal land cover changes could also be important to the stability of growing season rainfall.

\subsection{Changes in evaporation from land cover change}

The columns in Table 4 depicting potential land cover changes that increase or decrease evaporation, represent important land cover changes that could affect downwind precipitation. Here are some examples that can decrease evaporation. Irrigated land has high evaporation, but excessive irrigation can lead to salinisation of soils, and thus to abandonment of land altogether. Urbanization can lead to increased competition over arable land, converting high evaporation areas that are formerly rainfed and irrigated to lower evaporation urban areas. Forests also have high evaporation, and thus deforestation can significantly reduce evaporation (Bosch and Hewlett, 1982; Zheng and Eltahir, 1998; Gordon et al., 2005). Finally, land degradation in any land use category can also reduce evaporation because barren landscapes, with very low net primary production, have the lowest evaporation of all land covers. It should be noted that the actual effect of rigorous land cover change might very well be increased sensible heat fluxes and changes in wind patterns (e.g. Werth and Avissar, 2002; Makarieva and Gorshkov, 2007; Goessling and Reick, 2011).

Afforestation and increased irrigation can increase evaporation rates in the precipitationshed. It should be noted that an increase in evaporation does not necessarily lead to an increase in precipitation, because conditions that lead to convection must also be present; however, these conditions are usually present during the growing (rainy) season (e.g. Findell and Eltahir, 2003; Tuinenburg et al., 2011).

Table 4 contains plausible land cover changes that could have a large effect in the seven identified precipitationsheds. For example, in the Chinese precipitationsheds we expect to see increased salinisation of rice and irrigated croplands, primarily in Northern China (Molden, 2007). Extensive deforestation in Outer Mongolia may be counteracted by ongoing afforestation in the Gobi Desert (Hansen et al., 2010). 
Table 4. Analysis of the vulnerability of the sink regions to land cover changes in the precipitationsheds, in terms of (a) current land-use intensity, (b) whether land cover change is expected to increase/decrease precipitationshed evaporation, (c) the number of countries in the precipitationshed, and (d) the spatial size of the precipitationshed.

\begin{tabular}{|c|c|c|c|c|c|c|c|c|c|c|c|c|}
\hline \multirow[t]{2}{*}{ Region } & \multirow[t]{2}{*}{$\begin{array}{l}\text { Land- } \\
\text { use } \\
\text { Inten- } \\
\text { sity }\end{array}$} & \multicolumn{4}{|c|}{$\begin{array}{c}\text { Potential } \\
\text { Land-use } \\
\text { Changes } \\
\text { Decreasing } \\
\text { Evaporation in } \\
\text { the } \\
\text { Precipitationshed }\end{array}$} & \multicolumn{2}{|c|}{$\begin{array}{l}\text { Potential } \\
\text { Land-use } \\
\text { Changes } \\
\text { Increasing } \\
\text { Evapora- } \\
\text { tion in the } \\
\text { Precipita- } \\
\text { tionshed }\end{array}$} & \multirow[t]{2}{*}{$\begin{array}{l}\text { Number of } \\
\text { Nations in } \\
\text { Precipita- } \\
\text { tionshed }\end{array}$} & \multirow[t]{2}{*}{$\begin{array}{c}\text { Population } \\
\text { in Precipi- } \\
\text { tationshed } \\
\text { (millions of } \\
\text { people) }\end{array}$} & \multicolumn{2}{|c|}{$\begin{array}{l}70 \% \\
\text { Relative } \\
\text { Precipita- } \\
\text { tionshed } \\
\text { Area } \\
(\text { million } \\
\left.\mathrm{km}^{2}\right)\end{array}$} & \multirow[t]{2}{*}{$\begin{array}{l}\text { Sink } \\
\text { Region } \\
\text { Vulner- } \\
\text { ability } \\
\text { to } \\
\text { Land- } \\
\text { use } \\
\text { Change }\end{array}$} \\
\hline & & 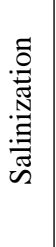 & 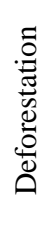 & 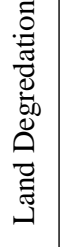 & 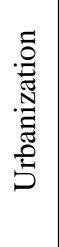 & 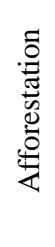 & 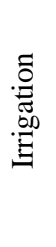 & & & $\stackrel{\bar{\pi}}{0}$ & 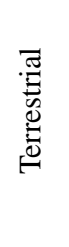 & \\
\hline Argentina & Med. & & $X$ & $\mathrm{X}$ & & & X & 7 & 114 & 19.4 & 7.2 & Med. \\
\hline $\begin{array}{l}\text { East } \\
\text { China }\end{array}$ & $\begin{array}{l}\text { Very } \\
\text { high }\end{array}$ & $\mathrm{X}$ & X & & $X$ & $X$ & & 29 & 2294 & 37.1 & 28.6 & High \\
\hline $\begin{array}{l}\text { Eastern } \\
\text { Sahel }\end{array}$ & High & & X & $X$ & & X & $X$ & 72 & 719 & 32.5 & 24.7 & Med. \\
\hline $\begin{array}{l}\text { North } \\
\text { China }\end{array}$ & High & $X$ & $X$ & $X$ & $\mathrm{X}$ & $X$ & $X$ & 23 & 1589 & 34.0 & 29.0 & High \\
\hline $\begin{array}{l}\text { Pakistan- } \\
\text { India }\end{array}$ & $\begin{array}{l}\text { Very } \\
\text { high }\end{array}$ & $X$ & & $X$ & & X & X & 16 & 184 & 38.4 & 26.7 & Med. \\
\hline $\begin{array}{c}\text { Southern } \\
\text { Africa }\end{array}$ & Med. & $X$ & & $X$ & & X & X & 15 & 135 & 14.0 & 6.5 & Med. \\
\hline $\begin{array}{l}\text { Western } \\
\text { Sahel }\end{array}$ & High & & X & $X$ & & X & X & 83 & 991 & 33.1 & 25.6 & Med. \\
\hline
\end{tabular}

Extensive urbanization is taking place, particularly in the eastern precipitationshed of the Northern China sink region (Chen, 2004). In the Pakistan-India precipitationshed we expect potential reductions in evaporation from abandonment of rice and irrigated cropland due to salinisation (Molden, 2007). However, this could be counteracted by afforestation in Europe (Foley et al., 2005). Both the Sahelian precipitationsheds are vulnerable to deforestation in the Congo and West Africa, the draining of the Sudd wetlands in the Nile Basin, as well as to degradation of rangelands and croplands within the sink regions themselves (Lambin et al., 2001; Hansen et al., 2010; Mohamed et al., 2004). However, irrigation expansion in the normally dry areas of Southern Europe and Northern Africa may increase evaporation in the
Sahelian precipitationsheds (Boucher et al., 2004). The Argentina precipitationshed is potentially vulnerable to deforestation east of the Andes, a major evaporation source, and from overgrazing in the Pampas (Viglizzo and Frank, 2006). This could potentially be counteracted by irrigation and water harvesting in the Pampas. Finally, in Southern Africa, overgrazing and salinisation in the surrounding areas of the sink region may reduce evaporation, while afforestation, irrigation, and water harvesting in nearby rangelands may increase evaporation (Stringer and Reed, 2007). 


\subsection{Assessing overall vulnerability of sink regions to land cover change}

In order to determine the potential sink region vulnerability to changes in upwind land-use (and evaporation), current land-uses were compared with observed and expected changes in land-cover. Of notable importance was considering whether there was a high potential for rangelands to expand, because of the susceptibility of these landscapes to transition to degraded states (Milton et al., 1994) (Table 3 and Table 4). We estimate the Chinese sink regions to have the highest vulnerability of the seven sink regions, primarily due to the fast-paced, potentially evaporation-altering land cover changes; e.g. expansion of urbanization, expansion of irrigated cropland, deforestation throughout East and Southeast Asia, and afforestation of Northern China. Additionally, the Chinese sink regions had the largest precipitationshed populations, both exceeding 1.5 billion people, suggesting there was a high potential for additional human-induced changes in land-cover. The other five sink regions have an estimated vulnerability of medium, because the impact of land cover change on evaporation is considered relatively balanced between increases and reductions in evaporation (Table 4).

\subsection{Climate change impacts to precipitationsheds}

In parallel with land use change, climate change can significantly alter the precipitationsheds via atmospheric impacts (e.g. large-scale changes in the jet stream), terrestrial impacts (e.g. changes in the distribution of terrestrial biomes) (e.g. Feddema et al., 2005), or coupling of the two. With climate change, current state of the art climate models predict a robust poleward migration of the mid-latitude jets, as well as an expansion of the Hadley Circulation (Meehl et al., 2003). Both of these consequences of anthropogenic climate change could affect the transport of moisture between source and sink regions in the precipitationsheds.

\subsection{Data reliability and the validation of the findings}

Several of the datasets have alternatives that enable crossvalidation. For example, to validate the precipitation backtracking and the resultant precipitationsheds in this study, another reanalysis dataset, such as NCEP (Kalnay et al., 1996) or MERRA (Bosilovich et al., 2011), could be employed to compare to the ERA Interim-based results (Berrisford et al., 2009). General intercomparisons of these datasets are given by Lorenz and Kunstmann (2011) and Trenberth et al. (2011) and show that ERA-Interim does a relatively good job compared to other reanalyses, particularly in the most recent decades. Likewise, the vulnerability analysis could be strengthened with explicit land-use change projections, rather than the literature review-based method employed herein.
However, in several cases the datasets are new releases, such as the rainfed cereal data (Portmann et al., 2010), and therefore cross-validation is considered difficult. Furthermore, some of the datasets lack a suitable alternative since they represent the "state-of-the-art", e.g. the Anthromes dataset (Ellis et al., 2010), and thus a suitable comparison for cross-validation of the results is not currently available.

\section{Summary and conclusions}

We have introduced and developed the concept of precipitationsheds, defined as the upwind atmosphere and surface that contributes evaporation to a specific location's precipitation. This analysis has aimed to further integrate the fields of moisture recycling, land cover change, and dryland, rainfed agriculture. We have focused the analysis on dryland rainfed agriculture because it is a livelihood that is particularly susceptible to even small changes in rainfall. Increased understanding regarding the sources of growing season rainfall for dryland farmers could lead to increased adaptive capacity on the farm (Boelee, 2011).

From a policy perspective, future water management in rainfed ecosystems may need to broaden to include coordination of land-use policies, from local to international levels. Precipitationshed management institutions, similar to transboundary river organizations like the Mekong River Commission, may be required to facilitate dialogue between upwind and downwind activities within the precipitationshed. Specifically, upwind and downwind stakeholders would need to have their respective rights acknowledged, specifically rights to pursue their own livelihoods. However, precipitationshed management institutions will understandably require rigorous quantitative simulations and analysis for any of their recommendations to be practical for use in government.

In the short-term, precipitationshed analysis may enable proactive assessments of the long-distance (teleconnected) effects of major land-use changes such as through REDD (Reducing Emissions from Deforestation and Forest Degradation), million-tree campaigns, or desertification trends.

Future work using the precipitationsheds framework should aim to quantify how specific land cover changes (e.g. from forest to savannah) affect local evaporation, and downwind precipitation. Likewise, it is important to understand how these affects to evaporation change with both latitude and season. This type of information may eventually provide dryland agricultural regions with enough information to adapt to significant changes in upwind land cover.

This work demonstrates that seemingly separate parts of Earth's biophysical system are interlinked with its social systems. Indeed, our results and analysis suggest that food security in some of the world's most water-constrained rainfed 
agricultural regions could be very sensitive to distant land cover changes.

\section{Supplement related to this article is available online at: http://www.biogeosciences.net/9/733/2012/ bg-9-733-2012-supplement.pdf.}

Acknowledgements. This research was supported by Mistra (the Swedish Foundation for Strategic Environmental Research), through a core grant to the Stockholm Resilience Centre, a cross-faculty research centre at Stockholm University. The investigations were also supported in part by; the Division for Earth and Life Sciences (ALW) with financial aid from the Netherlands Organization for Scientific Research (NWO); and by the Swedish Research Council Formas, and Ebba and Swen Schwartz Stiftelse. Thanks to Garry Peterson, Will Steffen, Jens Heinke, and Elizabeth A. Barnes for manuscript comments.

Edited by: H. P. Schmid

\section{References}

Allen, R., Pereira, L., Raes, D., and Smith, M.: Crop evapotranspiration - Guidelines for computing crop water requirements, Tech. Rep. FAO Irrigation and drainage paper 56, Food and Agriculture Organization of the United Nations, Rome, Italy, 1998.

Berrisford, P., Dee, D., Fielding, K., Fuentes, M., Ållberg, P. W.,Kobayashi, S., and Uppala, S. M.: The ERA-Interim archive, online, , 2009.

Bichet, A., Wild, M., Folini, D., and Schär, C.: Global precipitation response to changing forcings since 1870, Atmos. Chem. Phys., 11, 9961-9970, doi:10.5194/acp-11-9961-2011, 2011.

Boelee, E.: Ecosystems for water and food security, Tech. rep., International Water Management Institute and the United Nations Environment Programme, Nairobi, 2011.

Bosch, J. and Hewlett, J.: A review of catchment experiments to determine the effect of vegetation changes on water yield and evapotranspiration, J. Hydrol., 55, 3-23, 1982.

Bosilovich, M. and Chern, J. D.: Simulation of water resources and precipitation recycling for the MacKenzie, Mississippi, and Amazon River basins, J. Hydrometeorol., 7, 312-329, 2006.

Bosilovich, M. G., Robertson, F. R., and Chen, J.: Global Energy and Water Budgets in MERRA, J. Clim., 24, 5721-5739, doi:10.1175/2011jcli4175.1, 2011.

Boucher, O., Myhre, G., and Myhre, A.: Direct human influence of irrigation on atmospheric water vapour and climate, Clim. Dynam., 22, 597-603, 2004.

Brubaker, K. L., Entekhabi, D., and Eagleson, P. S.: Estimation of continental precipitation recycling, J. Clim., 6, 1077-1089, 2004.

Budyko, M.: Climate and Life, Academic Press Inc., New York, USA, 508 pp., 1974.

Center for International Earth Science Information Network (CIESIN), Columbia University; and Centro Internacional de Agricultura Tropical (CIAT). Gridded Population of the World, Version 3 (GPWv3). Palisades, NY: Socioeconomic Data and Applications Center (SEDAC), Columbia University, available online at: http://sedac.ciesin.columbia.edu/gpw, last access: 9 November 2011, 2005.
Chen, J.: Rapid urbanization in China: A real challenge to soil protection and food security, Catena, 69, 1-15, 2004.

Dallmeyer, A. and Claussen, M.: The influence of land cover change in the Asian monsoon region on present-day and mid-Holocene climate, Biogeosciences, 8, 1499-1519, doi:10.5194/bg-8-1499-2011, 2011.

Dee, D. P., Uppala, S. M., Simmons, A. J., Berrisford, P., Poli, P., Kobayashi, S., Andrae, U., Balmaseda, M. A., Balsamo, G., Bauer, P., Bechtold, P., Beljaars, A. C. M., van de Berg, L., Bidlot, J., Bormann, N., Delsol, C., Dragani, R., Fuentes, M., Geer, A. J., Haimberger, L., Healy, S. B., Hersbach, H., Hólm, E. V., Isaksen, L., Kå llberg, P., Köhler, M., Matricardi, M., McNally, A. P., Monge-Sanz, B. M., Morcrette, J. J., Park, B. K., Peubey, C., de Rosnay, P., Tavolato, C., Thépaut, J. N., and Vitart, F.: The ERA-Interim reanalysis: configuration and performance of the data assimilation system, Q. J. Roy. Meteor. Soc., 137, 553597, 2011.

Dekker, S. C., Rietkerk, M., and Bierkens, M. F. P.: Coupling microscale vegetation-soil water and macroscale vegetationprecipitation feedbacks in semiarid ecosystems, Global Change Biol., 13, 671-678, doi:10.1111/j.1365-2486.2007.01327.x, 2007.

Dirmeyer, P. and Brubaker, K.: Characterization of the Global Hydrologic Cycle from a Back-Trajectory Analysis of Atmospheric Water Vapor, J. Hydrometeorol., 8, 20-37, doi:10.1175/JHM557.1, 2007.

Dirmeyer, P. A., Brubaker, K. L., and DelSole, T.: Import and export of atmospheric water vapor between nations, J. Hydrol., 365, 11-22, 2009.

Dominguez, F. and Kumar, P.: Precipitation recycling variability and ecoclimatological stability - A study using NARR Data, Part I: Central U.S. plains ecoregion, J. Clim., 21, 5165-5186, 2008.

Ellis, E. C. and Ramankutty, N.: Putting people in the map: Anthropogenic biomes of the world, Frontiers Ecol. Environ., 6, 439447, 2008.

Ellis, E. C., Goldewijk, K. K., Siebert, S., Lightman, D., and Ramankutty, N.: Anthropogenic transformation of the biomes, 1700 to 2000, Global Ecol. Biogeogr., 19, 589-606, 2010.

Eltahir, E. and Bras, R.: Precipitation recycling in the Amazon basin, Q. J. Roy. Meteor. Soc., 120, 861-880, 1994.

Feddema, J. J., Oleson, K. W., Bonan, G. B., Mearns, L. O., Buja, L. E., Meehl, G. A., and Washington, W. M.: Atmospheric science: The importance of land-cover change in simulating future climates, Science, 310, 1674-1678, 2005.

Feddes, R., Hoff, H., Bruen, M., Dawson, T., De Rosnay, P., Dirmeyer, P., Jackson, R., Kabat, P., Kleidon, A., and Lilly, A.: Modeling root water uptake in hydrological and climate models, B. Am. Meteorol. Soc., 82, 2797-2810, 2001.

Findell, K. L. and Eltahir, E. A. B.: Atmospheric controls on soil moisture-boundary layer interactions, Part I: Framework development, J. Hydrometeorol., 4, 552-569, 2003.

Foley, J., DeFries, R., Asner, G., Barford, C., Bonan, G., Carpenter, S. R., Chapin, F. S., Coe, M. T., Daily, G. C., Gibbs, H. K., Helkowski, J. H., Holloway, T., Howard, E. A., Kucharik, C. J., Monfreda, C., Patz, J. A., Prentice, I. C., Ramankutty, N., and Snyder, P. K.: Global Consequences of Land Use, Science, 309, 570-574, doi:10.1126/science.1111772, 2005.

Foley, J. A., Ramankutty, N., Brauman, K. A., Cassidy, E. S., Gerber, J. S., Johnston, M., Mueller, N. D., O’Connell, C., Ray, D. 
K., West, P. C., Balzer, C., Bennett, E. M., Carpenter, S. R., Hill, J., Monfreda, C., Polasky, S., Rockstrom, J., Sheehan, J., Siebert, S., Tilman, D., and Zaks, D. P. M.: Solutions for a cultivated planet, Nature., 478, 337-342, doi.10.1038/nature10452, 2011.

Gerten, D., Schaphoff, S., Haberlandt, U., Lucht, W., and Sitch, S.: Terrestrial vegetation and water balance - Hydrological evaluation of a dynamic global vegetation model, J. Hydrol., 286, 249-270, 10.1016/j.jhydrol.2003.09.029, 2004.

Goessling, H. F. and Reick, C. H.: What do moisture recycling estimates tell us? Exploring the extreme case of nonevaporating continents, Hydrol. Earth Syst. Sci., 15, 3217-3235, doi:10.5194/hess-15-3217-2011, 2011.

Gordon, L. J., Steffen, W., Jönsson, B. F., Folke, C., Falkenmark, M., and Johannessen, A.: Human modification of global water vapor flows from the land surface, Proc. Natl. Acad. Sci. USA, 102, 7612-7617, 2005.

Hansen, M. C., Stehman, S. V., and Potapov, P. V.: Quantification of global gross forest cover loss, Proc. Natl. Acad. Sci. USA, 107, 8650-8655, 2010.

Hossain, F., Jeyachandran, I., and Pielke Sr, R. A.: Have Large Dams Altered Extreme Precipitation Patterns, Eos Trans. AGU, 90, 2009.

Jódar, J., Carrera, J. and Cruz, A.: Irrigation enhances precipitation at the mountains downwind, Hydrol. Earth Syst. Sci., 14, 2003 2010, doi:10.5194/hess-14-2003-2010, 2010.

Kalnay, E. , Kanamitsu, M., Kistler, R., Collins, W., Deaven, D., Gandin, L., Iredell, M., Saha, S., White, G., Woollen, J., Zhu, Y., Leetmaa, A., Reynolds, R., Chelliah, M., Ebisuzaki, W., Higgins, W., Janowiak, J., Mo, K. C., Ropelewski, C., Wang, J., Jenne, R., and Joseph, D.: The NCEP/NCAR 40-year reanalysis project, B. Am. Meteorol. Soc., 77, 437-470, 1996.

Kochendorfer, J. P. and Ramrez, J. A.: Ecohydrologic controls on vegetation density and evapotranspiration partitioning across the climatic gradients of the central United States, Hydrol. Earth Syst. Sci., 14, 2121-2139, http://dx.doi.org/10.5194/ hess-14-2121-2010doi:10.5194/hess-14-2121-2010, 2010.

Koster, R., Jouzel, J., Suozzo, R., Russell, G., Broecker, W., Rind, D., and Eagleson, P.: Global sources of local precipitation as determined by the NASA/GISS GCM, Geophys. Res. Lett., 13, 121-124, 1986.

Kunstmann, H. and Jung, G.: Influence of soil-moisture and land use change on precipitation in the Volta Basin of West Africa, Int. J. River Basin Manage., 5, 9-16, 2007.

Lambin, E., Turner, B., Geist, H., Agbola, S., Angelsend, A., Bruce, J., Coomes, O., Dirzo, R., Fischer, G., Folke, C., George, P., Homewood, K., Imbernon, J., Leemans, R., Li, X., Moran, E., Mortimore, M., Ramakrishnan, P., Richards, J., Skå nes, H., Steffen, W., Stone, G., Svedin, U., Veldkamp, T., Vogel, C., and Xu, J.: The causes of land-use and land-cover change: moving beyond the myths, Global Environ. Change, 11, 261-269, 2001.

Lettau, H., Lettau, K., and Molion, L. C.: Amozonia's hydrological cycle and the role of atmospheric recycling in assessing deforestation effects, Mon. Weather Rev., 107, 227-238, 1979.

Li, K. Y., Coe, M. T., Ramankutty, N., and Jong, R. D.: Modeling the hydrological impact of land-use change in West Africa, J. Hydrol., 337, 258-268, 2007.

Lorenz, C., and Kunstmann, H.: The hydrological cycle in three state-of-the-art reanalyses: intercomparison and performance analysis, J. Clim., submitted, 2011.
Millennium Ecosystem Assessment: Ecosystems and Human WellBeing: Synthesis, Island Press, 2005.

Makarieva, A. M. and Gorshkov, V. G.: Biotic pump of atmospheric moisture as driver of the hydrological cycle on land, Hydrol. Earth Syst. Sci., 11, 1013-1033, doi:10.5194/hess-11-10132007, 2007.

Meehl, G., Stocker, T., Collins, W., Friedlingstein, P., Gaye, A., Gregory, J., Kitoh, A., Knutti, R., Murphy, J., Noda, A., Raper, S., Watterson, I., Weaver, A., and Zhao, Z.: Global Climate Projections, in: Climate Change 2007: The Physical Science Basis, in: Contribution of Working Group I to the Fourth Assessment Report of the Intergovernmental Panel on Climate Change, edited by: Solomon, S., Qin, D., Manning, M., Chen, Z., Marquis, M., Averyt, K., and Tignor, M. and Miller, H., Cambridge University Press, Cambridge, UK, 2003.

Millán, M. M., Estrela, M. J., Sanz, M. J., Mantilla, E., Martín, M., Pastor, F., Salvador, R., Vallejo, R., Alonso, L., Gangoiti, G., Ilardia, J. L., Navazo, M., Albizuri, A., Artiñano, B., Ciccioli, P., Kallos, G., Carvalho, R. A., Andrés, D., Hoff, A., Werhahn, J., Seufert, G., and Versino, B.: Climatic feedbacks and desertification: the Mediterranean model, J. Clim., 18, 684-701, 2005.

Milton, S., Dean, W., du Plessis, M., and Siegfried, W.: A conceptual model of arid rangeland degradation, Bioscience, 44, 70-76, 1994.

Mohamed, Y., Bastiaanssen, W., and Savenije, H.: Spatial variability of evaporation and moisture storage in the swamps of the upper Nile studied by remote sensing techniques, J. Hydrol., 289, 145-164, 2004.

Molden, D.: Water for food, water for life: a comprehensive assessment of water management in agriculture, Earthscan, London, UK, 2007.

Monfreda, C., Ramankutty, N., and Foley, J.: Farming the planet: 2. Geographic distribution of crop areas, yields, physiological types, and net primary production in the year 2000, Global Biogeochem. Cy., 22, 1-119, doi:10.1029/2007GB002947, 2008.

New, M., Lister, D., Hulme, M., and Makin, I.: A high-resolution data set of surface climate over global land areas, Clim. Res., 21, 1-25, 2002.

Nieto, R., Gimeno, L., and Trigo, R. M.: A Lagrangian identification of major sources of Sahel moisture, Geophys. Res. Lett., 33 , L18707, doi:10.1029/2007GB002947, 2006.

Numaguti, A.: Origin and recycling processes of precipitating water over the Eurasian continent: experiments using an atmospheric general circulation model, J. Geophys. Res., 104, 1957-1972, 1999.

Pielke Sr, R. A., Adegoke, J., Beltrán-Przekurat, A., Hiemstra, C. A., Lin, J., Nair, U. S., Niyogi, D., and Nobis, T. E.: An overview of regional land-use and land-cover impacts on rainfall, Tellus Ser. B-Chem. Phys. Meteorol., 59, 587-601, 2007.

Pitman, A. J., de Noblet-Ducoudré, N., Cruz, F. T., Davin, E. L., Bonan, G. B., Brovkin, V., Claussen, M., Delire, C., Ganzeveld, L., Gayler, V., van den Hurk, B. J. J. M., Lawrence, P. J., van der Molen, M. K., Müller, C., Reick, C. H., Seneviratne, S. I., Strengers, B. J., and Voldoire, A.: Uncertainties in climate responses to past land cover change: First results from the LUCID intercomparison study, Geophys. Res. Lett., 36, L14814, doi:10.1029/2009g1039076, 2009.

Portmann, F., Siebert, S., and Döll, P.: Global monthly irrigated and rainfed crop areas around the year 2000: a new high-resolution 
data set for agricultural and hydrological modeling, Global Biogeochem. Cy., 24, doi:10.1029/2008GB003435, 2010.

Ramankutty, N. and Foley, J.: Characterizing patterns of global land use: an analysis of global croplands data, Global Biogeochem. Cy., 12, 667-685, 1998.

Ramankutty, N. Evan, A., Monfred, C., and Foley, J.: Farming the planet: 1. Geographic distribution of global agricultural lands in the year 2000, Global Biogeochem. Cy., 22, 1-19, doi:10.1029/2007GB002952, 2008.

Reynolds, J., Smith, D., Lambin, E., Turner II, B., Mortimore, M., Batterbury, S., Downing, T., Dowlatabadi, H., Fernández, R., Herrick, J., Huber-Sannwald, E., Jiang, H., Leemans, R., Lynam, T., Maestre, F., Ayarza, M., and Walker, B.: Global desertification: building a science for dryland development, Global Biogeochem. Cy., 316, 847-851, doi:10.1126/science.1131634, 2007.

Rockström, J. and Karlberg, L.: Zooming in on the global hotspots of rainfed agriculture in water-constrained environments, in: Rainfed Agriculture: Unlocking the Potential, edited by: Wani, S., Rockström, J., and Oweis, T., 46-43, CAB International, UK, 2009.

Rockström, J., Falkenmark, M., Karlberg, L., Hoff, H., Rost, S., and Gerten, D.: Future water availability for global food production: The potential of green water for increasing resilience to global change, Water Resour. Res., 45, W00A12, doi:10.1029/2007WR006767, 2009.

Rost, S., Gerten, D., and Heyder, U.: Human alterations of the terrestrial water cycle through land management, Adv. Geosci., 18, 43-50, doi:10.5194/adgeo-18-43-2008, 2008

Savenije, H. H. G.: New definitions for moisture recycling and the relationship with land-use changes in the Sahel, J. Hydrol., 167, 57-78, 1995.

Savenije, H. H. G.: Water scarcity indicators; the deception of the numbers, Phys. Chem. Earth., 25, 199-204, 2000.
Soden, B. and Held, I.: An Assessment of Climate Feedbacks in Coupled Ocean-Atmosphere Models, J. Clim., 19, 3354-3360, doi:10.1175/JCLI3799.1, 2006.

Stringer, L. and Reed, M.: Land degradation assessment in Southern Africa: Integrating local and scientific knowledge bases, Land Degrad. Dev., 18, 99-116, doi:10.1002/ldr.760, 2007.

Thenkabail, P., Biradar, C., Noojipady, P., Dheeravath, V., Li, Y., Velpuri, M., Gumma, M., Gangalakunta, O., Turral, H., Cai, X., Vithanage, J., Schull, M., and Dutta, R.: Global irrigated area map (GIAM), derived from remote sensing, for the end of the last millennium, Int. J. Remote Sens., 30, 3679-3733, 2009.

Tuinenburg, O. A., Hutjes, R. W. A., Jacobs, C. M. J., and Kabat, P.: Diagnosis of local land-atmosphere feedbacks in India, J. Clim., 24, 251-266, 2011.

van der Ent, R. J. and Savenije, H. H. G.: Length and time scales of atmospheric moisture recycling, Atmos. Chem. Phys., 11, 18531863, doi:10.5194/acp-11-1853-2011, 2011.

van der Ent, R. J., Savenije, H. H. G., Schaefli, B., and Steele-Dunne, S. C.: Origin and fate of atmospheric moisture over continents, Water Resour. Res., 46, W09525, doi:10.1029/2010WR009127, 2010.

Viglizzo, E. and Frank, F.: Ecological interactions, feedbacks, thresholds and collapses in the Argentine Pampas in response to climate and farming during the last century, Quatern. Int., 158, 122-126, 2006.

Walther, G., Post, E., Convey, P., Menzel, A., Parmesan, C., Beebee, T., Fromentin, J., Hoegh-Guldberg, O., and Bairlein, F.: Ecological responses to recent climate change, Nature, 416, 389-395, 2002.

Werth, D. and Avissar, R.: The local and global effects of Amazon deforestation, J. Geophys. Res., 107, 8087 pp., 2002.

Zheng, X. and Eltahir, E.: The role of vegetation in the dynamics of West African monsoons, J. Clim., 11, 2078-2096, 1998. 